Gavryliak V.V.

viktoriia.gavryliak@gmail.com

https://orcid.org/0000-0003-1535-6416

Senior Lecturer, Romance and Germanic Philology Department, Luhansk Taras Shevchenko National University

Poltava, Ukraine

\title{
LINGUISTIC MANIPULATION IN CAMPAIGN SPEECHES OF DONALD TRUMP
}

The study of political discourse is of paramount importance in a democratic society, because democracy is not a mere set of procedures to be exercised but rather dialogic interaction between the government and the people, political groups and the society, social movements and individuals.

The problem of this research is especially topical due to the circumstances Ukraine is experiencing today in the context of this year presidential race.

The rhetoric Donald Trump used within his presidential campaign was far from the established political discourse in the USA. Trump criticized allies, and praised enemies. Moreover, he reprobated opponents, religious groups, the disabled, women, etc. However, in spite of this fact, or probably due to it, his popularity grew and he was the one to win the elections. This phenomenon stimulated this scientific effort and contributed to the results of the analysis presented below.

The problem of political discourse and the way it is affected by various means of linguistic manipulation has been studied by A. Akopova, T. Van Dijk, I. Fairclough, T. Kow, L. Stosic and others.

The aim of our research is to analyze the way linguistic manipulation manifested itself in campaign speeches of Donald Trump.

In order to be able to achieve the aim set above, we will consider political discourse in general, the nature of linguistic manipulation and, finally, find out how the latter was actualized by Donald Trump in his speeches within the presidential race.

In our research, we have analyzed three speeches by Donald selected according to three criteria: campaign;

1. the speeches should represent the key moments in the presidential

2. they should be intended for a wide audience;

3. they should cover the whole time span of the campaign.

Based on the criteria given above, we have selected the three speeches: 
1. The speech delivered on June 16, 2015 in New York City when the candidacy of Donald Trump was announced (47:08). The number of utterances - 921 .

2. Donald Trump New York City speech on stakes of the election (41:10) dated 06/22/2016. The number of utterances - 188 .

3. The inaugural address of Donald Trump on January 22, 2017 (16:00). The number of utterances - 107.

According to the aim of our research, we have analyzed the transcripts of the three speeches. The transcripts were retrieved from such reliable sources:

1. Speech $1-$ www.time.com

2. Speech 2 - www.politico.com

3. The Inaugural Address - www.whitehouse.gov

It is essential to clarify the notion of political discourse as a genre before looking into peculiarities of a presidential speech. This is due to the fact that political discourse has its comparatively established pattern of arrangement, its own style and structure.

One of the leading scholars involved into the study of political discourse Teun Van Dijk defines discourse as political when it has a direct functional role as a form of political action in the political process. Furthermore, it is contextualized in such communicative events as cabinet meetings, parliamentary sessions, election campaigns, rallies, interviews with the media, bureaucratic practices, protest demonstrations, and so on (Van Dijk, 1997).

From the point of view of other two theoreticians Isabela Fairclough and Norman Fairclough, political discourse is created for the purpose of argumentation (Fairclough, 2009). Due to this purely pragmatic nature of political discourse, it is aimed at persuasion, which in its turn has an impact on the organization of speeches and presentation of ideology in them. Therefore, analyzing this discourse critically helps to make these ideologies explicit.

According to van Dijk, ideologies consist of values that represent the basic guidelines for social perception and interaction. These ideologies are socially shared and have the function of defining social identity (Van Dijk, 1997).

In order to impose these ideologies, there must be a leader capable of communicating them properly to the public. However, the speech itself has to be carefully constructed and organized, so that it also contributed to creation of the necessary reality for the audience, thus manipulating their consciousness.

Psychological manipulation can be defined as the exercise of undue influence through mental distortion and emotional exploitation, with the intention to seize power, control, benefits and/or privileges at the victim's expense (Preston, 2015).

The wide and blurred semantic filed of the term ,manipulation” includes such key elements as ,negative” intention of the speaker and covert character of influence. Manipulative functions of discourse create covert, disguised layer 
of linguistic data that is not easily separated from purely informational content (Beard, 2000).

It would be fair enough to state that manipulative discourse occupies an intermediate position between the truth and a lie. It could be also viewed as the type of truth the addresser wants his audience to believe and to accept as the only and the genuine one.

Linguistic manipulation is influence exercised by one person upon another or a group of people through speech and non-verbal means oriented towards achieving a certain goal that consists in changing of the addressee's behavior, perceptions and intentions in the course of communicative interaction (Akopova, 2013).

Due to the application of linguistic manipulation the addressee (the reader or the listener) does not perceive the information contained in verbal messages critically, being misled and reacting with the emotions the addresser had aimed at. This leads to the construction of the reality beneficial for the addresser (the speaker or the writer).

It should be emphasized that the way the information intended for manipulation is represented is vitally important. Written texts appear to be less notorious in the application of various strategies and techniques of linguistic manipulation. The reader can at any time get back to them, reread and retrieve the information contained repeatedly. This contributes to the critical perception of a messages.

However, when we deal with oral information, the situation is absolutely different. When listening, we concentrate on the meaning. It is impossible to stop the speaker in order to have time to analyze what has just been said. If the speech is well structured, has a definite aim and the speaker makes effective use of non-verbal means of communication, this information can have a great influence on the listeners. Thus, this influence can be several times greater than that of written messages.

These and other factors create foundation for basic classification types of linguistic manipulation highlighted in linguistic literature and works in the field of psychology (Akopova, 2013).

Depending on the sphere of mental activity participating and dominating in the process of communication, linguistic manipulation is divided into rational and emotional. In his attempts to influence interlocutor's behavior, the speaker can affect his rational sphere. To do this he uses convincing facts and arguments affecting people's consciousness. The aim of emotional manipulation is expression of the speaker's emotions and acquisition of responsive emotional reaction from the listener that would lead to changes in his behavior (Akopova, 2013).

Speeches of Donald Trump within his presidential campaign are dominated by emotional manipulation. We have identified 842 (67\%) utterances that address the emotional sphere of the audience. See some examples below. 
That all changes - starting right here, and right now, because this moment is your moment: it belongs to you. This is your day. This is your celebration (The Inaugural Address, 2017).

When do we beat Mexico at the border? They're laughing at us, at our stupidity. And now they are beating us economically. They are not our friend, believe me. But they're killing us economically (Donald Trump's Presidential Announcement Speech, 2015).

D. Trump appeals to emotions with the help of addressing the audience directly, the use of rhetorical questions and derogatory remarks.

The rational manipulation is less numerous in his messages.

E.g. Our trade deficit with China soared 40\% during Hillary Clinton's time as Secretary of State - a disgraceful performance for which she should not be congratulated, but rather scorned (Donald Trump NYC speech on stakes of the election, 2016).

According to the character of subject-object interaction, manipulation can be direct when the subject is openly presenting his demands to the object of manipulation and indirect when the manipulation is directed at the environment rather than at the object. Direct method of linguistic manipulation includes such forms of the language system that are associated with certain meaning directly expressing corresponding illocution, i.e. the aim of the communicative (Akopova, 2013).

Indirect manipulation significantly prevails $(90 \%)$ in the material analyzed within the frames of this research. Trump constantly uses the personal pronoun „we", refers to the people as ,the nation” and „Americans”.

We will build the greatest infrastructure on the planet earth - the roads and railways and airports of tomorrow (Donald Trump NYC speech on stakes of the election, 2016).

At the center of this movement is a crucial conviction: that a nation exists to serve its citizens.

Americans want great schools for their children, safe neighborhoods for their families, and good jobs for themselves (The Inaugural Address, 2017).

According to awareness of linguistic actions, manipulation can be intentional and non-intentional.

In case of intentional linguistic manipulation, the subject aims at a definite result on the part of the object of manipulation. Non-intentional linguistic manipulation is exercised involuntary, as the subject does not aim at achieving results from the listener (Akopova, 2013).

It is obvious that political discourse has a clearly pragmatic function of persuasion, especially if we deal with a pre-election campaign, which is naturally aimed at shaping the views of the audience according to the ideology of the candidate and, thus, getting their votes. Therefore, we strongly believe that nearly $100 \%$ of Donald Trump's speeches represent intentional manipulation.

According to the type of linguistic action, manipulation can be social, volitional and estimative (Akopova, 2013). 
Social manipulation that manifests itself clichés in the form of greetings, oaths and prayers, was observed in 226 utterances (18\%).

Here is my promise to the American voter:

If I am elected President, I will end the special interest monopoly in Washington, D.C. (Donald Trump NYC speech on stakes of the election, 2016).

The volitional manipulation was absolutely absent in the material analyzed due to the fact that it is realized in the form of orders, requests, refusals, advise. It is well-known that a presidential candidate is not yet entitled to any decisions, orders or official requests.

The estimative manipulation which sets public moral, legal, interpersonal emotional relations in the form of reprobation, praise, accusation, insult or threat abounds in the three speeches of Trump (more than $60 \%$ ). It is mostly criticism directed towards the Clintons (48\%) and Barack Obama (12\%).

Together, she and Bill made \$153 million giving speeches to lobbyists, CEOs, and foreign governments in the years since 2001.

Hillary Clinton who, as most people know, is a world class liar -just look at her pathetic email and server statements, or her phony landing in Bosnia where she said she was under attack but the attack turned out to be young girls handing her flowers, a total self-serving lie.

Hillary Clinton gave China millions of our best jobs, and effectively let China completely rebuild itself.

In return, Hillary Clinton got rich! (Donald Trump NYC speech on stakes of the election, 2016)

We have a disaster called the big lie: Obamacare. Obamacare (Donald Trump's Presidential Announcement Speech, 2015).

According to the addressee's reaction, we distinguish the following types of linguistic manipulation:

evaluative (changing of the subject-object relation);

emotional (formation of general emotional mood);

rational (reconstruction of categorical structure of individual conscience, introduction of new categories) (Akopova, 2013).

These are revealed in the feedback we get from the receiver or the object of manipulation. In our case, it was demonstrated by the results of the US presidential race 2016. While Trump lost the popular vote by nearly 3 million votes, he won the Electoral College vote, 304 to 227.

To conclude, the research shows that Donald Trump took an advantage of carefully constructed speeches aimed at manipulating the emotional sphere of the audience. The results of this scientific effort can be used for the further study of the problem of the linguistic manipulation strategies with the account of the non-verbal component of communication. 


\section{Список використаної літератури}

1. Van Dijk T. A. What is Political Discourse Analysis // Belgian Journal of Linguistics. 1997. № 11. pp. 11-52. 2. Fairclough I., Fairclough N. Political Discourse Analysis: A Method for Advanced Students. London: Routledge, 2012. 266 p. 3. Preston Ni. Fourteen Signs of Psychological and Emotional Manipulation. Psychology Today. URL: http://www.psychologytoday.com/us/blog/communication-success/201510/ (дата звернення 11.04.2019). 4. Beard A. The Language of Politics. London, New York: Routledge, 2000. 136 p. 5. Akopova A. Linguistic Manipulation: Definition and Types. International Journal of Cognitive Research in Science, Engineering and Education. 2013. Vol. 1. №2. URL: https://www.academia.edu/5491592/LINGUISTIC MANIPULATION DEFINITIO N AND TYPES (дата звернення 2.04.2019). 6. The Inaugural Address. URL: https://www.whitehouse.gov/briefings-statements/the-inaugural-address/ (дата звернення 15.03.2019). 7. Donald Trump's Presidential Announcement Speech. Time USA. URL: http://time.com/3923128/donald-trumpannouncement-speech/ (дата звернення 18.03.2019). 8. Donald Trump NYC Speech on Stakes of the Election. Politico LLC. URL: https://www.politico.com/story/2016/06/transcript-trump-speech-on-the-stakes -of-the-election-224654 (дата звернення 20.03.2019).

\section{References}

1. Van Dijk T. A. (1997). What is Political Discourse Analysis. Belgian Journal of Linguistics. № 11. pp. 11-52. 2. Fairclough I., Fairclough N. (2012). Political Discourse Analysis: A Method for Advanced Students. London: Routledge. 3. Preston Ni. (2015). Fourteen Signs of Psychological and Emotional Manipulation. Psychology Today. Retrieved from http://www.psychologytoday.com/us/blog/communication-success/201510/.

4. Beard A. (2000). The Language of Politics. London, New York: Routledge. 5. Akopova A. (2013). Linguistic Manipulation: Definition and Types. International Journal of Cognitive Research in Science, Engineering and Education. Vol. $\quad$ 1. №2. $\quad$ Retrieved from https://www.academia.edu/5491592/LINGUISTIC_MANIPULATION_DEFI NITION_AND_TYPES. 6. The Inaugural Address. (2017). Retrieved from https://www.whitehouse.gov/briefings-statements/the-inaugural-address/.

7. Donald Trump's Presidential Announcement Speech. (2015). Time USA. Retrieved from http://time.com/3923128/donald-trump-announcement-speech/. 8. Donald Trump NYC Speech on Stakes of the Election. (2016). Politico LLC. Retrieved from https://www.politico.com/story/2016/06/transcript-trumpspeech-on-the-stakes -of-the-election-224654.

Гавриляк В.В. Лінгвістична маніпуляція в передвиборчих промовах Дональда Трампа

У статті розглядається мовна маніпуляція, а саме те, яким чином iї було використано в передвиборчих виступах Дональда Трампа. Задля 
досягнення поставленої мети, автор досліджував проблему політичного дискурсу в цілому, природу лінгвістичних маніпуляцій i, нарешті, як саме Дональд Трамп застосовував iii y своїх виступах у межах президентської передвиборчої кампанії. У дослідженні було визначено поняття політичного дискурсу як жанру перед тим, як розглядати особливості президентської мови. Це пов'язано з тим, що політичний дискурс має свою порівняно встановлену структуру і власний стиль. Маніпулятивні функції дискурсу створюють прихований, замаскований шар лінгвістичних даних, який нелегко відокремлюється від суто інформаційного змісту. Лінгвістичну маніпуляцію було визначено як вплив, що здійснюється однією особою на іншу або групу людей через мовні та невербальні засоби. Дослідження показало, що Дональд Трамп успішно скористався ретельно сконструйованими промовами, спрямованими на маніпулювання емоційною сферою аудиторії.

Ключові слова: політичний дискурс, ідеологія, маніпуляція, лінгвістична маніпуляція.

Гавриляк В.В. Лингвистическая манипуляция в предвыборных выступлениях Дональда Трампа

В статье рассматривается языковая манипуляция, а именно то, каким образом она была использована в предвыборных выступлениях Дональда Трампа. Для достижения поставленной цели, автор исследовал проблему политического дискурса в целом, природу лингвистической манипуляции и, наконец, то, каким образом Дональд Трамп применял ее в своих выступлениях в рамках президентской предвыборной кампании. В исследовании было определено понятие политического дискурса как жанра перед тем, как рассматривать особенности президентской речи. Это связано с тем, что политический дискурс имеет свою сравнительно установленную структуру и собственный стиль. Манипулятивные функции дискурса создают скрытый, замаскированный слой лингвистических данных, который нелегко отделяется от чисто информационного содержания. Лингвистическую манипуляцию было определено как воздействие, которое осуществляется одним человеком на другого или на группу людей через языковые и невербальные средства. Исследование показало, что Дональд Трамп успешно воспользовался тщательно сконструированными речами, направленными на манипулирование эмоциональной сферой аудитории.

Ключевые слова: политический дискурс, идеология, манипуляция, лингвистическая манипуляция.

Gavryliak V.V. Linguistic manipulation in campaign speeches of Donald Trump

The article considers the way linguistic manipulation manifested itself in campaign speeches of Donald Trump. In order to be able to achieve the aim set, the author investigated the problem of political discourse in general, the 
nature of linguistic manipulation and, finally, found out how the latter was actualized by Donald Trump in his speeches within the presidential race. It is essential to clarify the notion of political discourse as a genre before looking into peculiarities of a presidential speech. This is due to the fact that political discourse has its comparatively established pattern of arrangement, its own style and structure. Manipulative functions of discourse create covert, disguised layer of linguistic data that is not easily separated from purely informational content. Linguistic manipulation is influence exercised by one person upon another or a group of people through speech and non-verbal means oriented toward achieving a certain goal that consists in changing of the addressee's behavior, perceptions and intentions in the course of communicative interaction. The research shows that Donald Trump took an advantage of carefully constructed speeches aimed at manipulating the emotional sphere of the audience. The results of this scientific effort can be used for the further study of the problem of the linguistic manipulation strategies with the account of the non-verbal component of communication.

Key words: political discourse, ideology, manipulation, linguistic manipulation.

Стаття надійшла до редакції - 27.03.2019 р. Стаття прийнята до друку - 29.03.2019 р. Рецензент - к.філ.н, доц. ЛНУ імені Тараса Шевченка, Савельєва Н.О. 